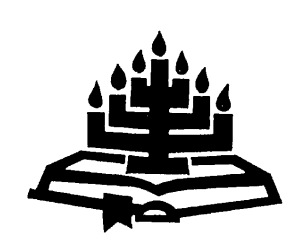

\title{
Paulus se beskouing van Jesus
}

\author{
F.P. Viljoen \\ Skool vir Bybelwetenskappe en Bybeltale \\ Potchefstroomkampus \\ Noordwes-Universiteit) \\ POTCHEFSTROOM \\ E-pos: sbbfpv@puk.ac.za
}

\begin{abstract}
Paul's views on Jesus

Many scholars distinguish between the nature of Jesus and his teachings as evident during His days on earth, and that of Christ after the resurrection. It is often assumed and argued that Paul's views and argumentations were responsible for this distinction. If exegetical investigation is, however, taken as point of departure it seems as if this distinction is not justifiable. Although Paul specifically emphasises the importance of cross and resurrection, Jesus' earthly existence is also regarded as important by him. Paul's overall viewpoint reveals that he maintains an existing continuity between these two facets of Christ's existence. The acknowledgement of the existence of the earthly Jesus qualifies the appropriation of the exalted Christ. Likewise, the surety of the exalted Christ is identified by the reality of the earthly Jesus. Based on this point of view Paul regards the words of Jesus as absolutely authoritative. Paul's Christology implies nothing other than an interpretation of Jesus' life and death in the light of the resurrected and everpresent Lord.
\end{abstract}

\section{Opsomming \\ Paulus se beskouing van Jesus}

Talle navorsers onderskei tussen die aard van Jesus en sy leringe soos duidelik gedurende sy dae op aarde en dié van Christus soos na die opstanding. Dit word dikwels aanvaar en beredeneer dat Paulus se sienings en beredenerings verantwoordelik was vir hierdie onderskeid. Indien eksegetiese ondersoek egter as vertrekpunt geneem word, blyk dit dat hierdie onderskeid nie geregverdig is nie. Hoewel Paulus die belangrikheid van die kruis en opstanding spesifiek benadruk, is die 
bestaan van die aardse Jesus vir hom eweneens belangrik. Paulus se omvattende standpunt openbaar dat hy dit onderskryf dat daar 'n kontinue lyn is tussen die twee fasette van Jesus se bestaan. Die erkenning van die bestaan van die aardse Jesus kwalifiseer die aanvaarding van die verhoogde Christus. Op soortgelyke wyse word die sekerheid van die verhoogde Christus geïdentifiseer met die werklikheid van Jesus se aardse bestaan. Op grond van hierdie siening kan afgelei word dat Paulus die uitsprake van Jesus as absoluut gesaghebbend beskou. Paulus se Christologie impliseer niks anders nie as 'n interpretasie van Jesus se lewe en dood in die lig van die opgestane en altyd teenwoordige Here.

\section{Inleiding}

Talle navorsers maak 'n skeiding tussen die "historiese Jesus"1 en die Christus van die geloof (vgl. Wilson, 1984:18). Hierdie breuk word dikwels aan Paulus toedig.

Van Aarde (2002:519) redeneer byvoorbeeld dat die evangelie vir Paulus die aankondiging van 'n gebeure was, van 'n stuk geskiedenis (die kruis) wat onafskeibaar verbind was met iets (die opstanding). Vanuit moderne empiriese perspektief beskou Van Aarde die opstanding egter nie as geskiedenis nie. In die lig van die Mediterreense premoderne denke beskou hy die opstanding eerder in terme van die verwysing van "'n alter staat van bewussyn" (Van Aarde, 2001:184-187 se skryfwyse en gebruik van die term). Die opgestane Christus kan daarom nie deel vorm van die historiese Jesus nie.

In aansluiting by die skynbare breuk tussen die historiese Jesus en die Christus van die geloof volgens Paulus, word dikwels opgemerk dat Paulus in die geheel van sy briewe minimaal na die aardse Jesus verwys (Dunn, 1998:184; Snyman, 1977:229; Wilson, 1984: 18). Gevolglik word aanvaar dat Paulus weinig kennis gedra het of belanggestel het in die aardse Jesus. Sommige navorsers lei ook daaruit af dat daar 'n Christologiese verskil tussen Paulus en die Evangelies ${ }^{2}$ bestaan. Hellenistiese invloede in die teologie van

1 Die term "historiese Jesus" is 'n gelade begrip en spruit uit 'n benadering van die post-Verligting. Die uiterste konsekwensie kan daarop dui dat die historiese Jesus opgediep moet word uit die mitologiese beeld wat rondom die aardse Jesus gebou is.

2 Aangesien die Evangelies die verhaal van Jesus in kerugmatiese styl weergee, kom die historiese beeld van Jesus in die Evangelies uiteraard ook onder verdenking deur die historiese-kritiese benadering. 
Paulus sou die oorsaak wees vir hierdie breuk. Ondersoeke word dan gedoen om vas te stel watter invloed Paulus se herkoms, agtergrond, opvoeding, oorname van tradisies, verhouding tot ander apostels en die gemeentes, sy bekering en sy arbeid onder die heidene op sy beskouing van en verhouding tot die aardse Jesus gehad het (vgl. Bornkamm, 1975:228; Floor, 1982:4; Hunter, 1966:77; Schmithals, 1962:159-160). Dit sou tot 'n gebrekkige en selfs 'n verdraaide beeld van die aardse Jesus by Paulus lei.

Die vraag kan egter gestel word of Paulus se verwysings na die aardse Jesus moontlik sou wees sonder 'n begrip van wie Jesus was en wat die aard en omvang van sy optrede en verkondiging was. Voorts kan gevra word of 'n benadering van weerstand of beweerde onbekendheid met die ware menslikheid van Jesus nie lei tot ' $n$ vorm van Dosetisme in die huidige teologie nie.

Wanneer gepraat word van Paulus se prediking, moet onderskei word tussen sy preke wat opgeteken is in Handelinge en die corpus Paulinum (Paulus se briewe). Hierdie ondersoek fokus op die corpus Paulinum.

Hierdie artikel poog om die volgende aspekte te betrek:

- om 'n kort oorsig te bied van die vraagstukke in die betrokke navorsing en die geldigheid van die opvatting te toets of Paulus wel so min inligting gee oor die aardse Jesus;

- of daar inderdaad 'n breuk tussen Jesus en Paulus se siening van Christus bestaan het;

- of Paulus moontlik 'n invloed kon uitoefen in die ontstaan en ontwikkeling van 'n geloof in die opgestane Christus, wat strydig sou wees met Jesus se bedoeling.

In die lig hiervan word ondersoek watter betekenis die aardse lewe van Jesus vir die prediking van Paulus volgens die corpus Paulinum gehad het. Ten einde hierdie ondersoek binne konteks te plaas, word eers aandag gegee aan die historiese verloop van die navorsing wat reeds gedoen is. Daarna volg 'n beoordeling van hierdie navorsing deur ' $n$ aantal gedeeltes in die corpus Paulinum waar die aardse Jesus as sodanig aan die orde kom, eksegeties te ondersoek.

\section{Historiese verloop van navorsing oor Jesus en Paulus}

Die vraagstuk oor die verhouding tussen die historiese Jesus en die siening van Jesus volgens Paulus, is die afgelope eeue met 
wisselende intensiteit ondersoek (vgl. Dunn, 1998:182-184; Ridderbos, 1971:5-13). Kernvraagstukke in dié ondersoek word vervolgens kortliks bespreek.

\section{1 F.C. Baur}

Met F.C. Baur (die vader van die sogenaamde Tübingen-skool) se opspraakwekkende hipotese van 'n teenstelling tussen die Pauliniese en Petriniese Christendom, het die vraag na die historiese Jesus in hierdie geskrifte reeds in die negentiende eeu aan die orde gekom. Baur het vanuit Paulus se siening terugskouend vrae oor Jesus gevra. Hy toon verskille aan en beskou die verskille as die resultaat van 'n historiese ontwikkelingsproses. Hy definieer die Nuwe Testament as "die christliche Dogmengeschichte in ihrem Verlauf innerhalb des neuen Testaments" (Baur, 1973 [1864]:33). Hierby deel hy die Nuwe Testament volgens verskillende ontwikkelingsperiodes in. Die eerste periode, dié oor Jesus, lê buite die historiese ontwikkeling en word as die oerperiode beskou. $\mathrm{Na}$ die dood van Jesus het daar voortgang gekom soos wat dit in die corpus Paulinum aan die orde kom. Die dood van Jesus moet beskou word as "das wichtigste Moment des Entwicklungsprozessen, durch welchen das Christentum eine von seiner ursprünglichen Form wesentlich verschiedene Gestalt erhielt" (Baur, 1973 [1864]:128).

\subsection{Heinrich Holtzmann}

In die "nachbaursche" periode (vgl. Kümmel, 1958:176) is die insigte van Baur deur verskeie navorsers verder ondersoek. In hierdie studies kom die groeiende oortuiging van Griekse invloede op Paulus se denke na vore. Die sogenaamde teenstelling tussen Joodse en Griekse elemente in sy leer is telkens in dié verband bespreek. Die verhouding tussen die aardse Jesus en Paulus se prediking kom selde aan die orde. Paulus word eerder as ' $n$ grootheid selfstandig gesien en so van die "oer-Christendom" geïsoleer (Schweizer, 1911:33). Holzmann gaan daarvan uit dat, naas Paulus se Joodse agtergrond, daar ook aansienlike Griekse invloed in sy denke merkbaar is (Holzmann, 1897:2). Die presiese verhouding tussen die Joodse en Griekse elemente vorm die kernvraag waarop Holzmann sy ondersoek rig.

As diaspora-Jood sou Paulus ontvanklik wees vir Griekse invloede. Dit sou tot gevolg hê dat Paulus se beeld van Christus binne 'n kort tydsbestek tot "kolossale Dimensionen" (Holzmann, 1897:25) groei. Paulus sou hierdie Christologiese skema verbind aan die aardse 
Jesus. Die gevolg is dat die leer en lewe van die aardse Jesus by Paulus al meer op die agtergrond geraak het om plek te maak vir Paulus se eie Christologiese skema. In plaas van Jesus se eie verkondiging, sou $\mathrm{Hy}$ as Persoon eerder die voorwerp van geloof word. Dit sou beter byval vind by die nie-Palestynse gehoor van Paulus as heidenapostel.

\subsection{William Wrede}

Wrede (1907:94) was onder die indruk van 'n diepliggende verskil tussen Paulus en Jesus. Volgens Wrede (1907:60) het Paulus Jesus vermoedelik nooit gesien nie. Wat Paulus indirek van Jesus verneem het, het eerder van hom 'n vervolger as volgeling van Jesus gemaak. Daarbenewens was dit vir Wrede opvallend dat Paulus so min van die lewe van Jesus vermeld en alle nadruk op die dood van Jesus lê.

Die belangrikste vraag vir Wrede was hoe dit moontlik is dat Paulus in sy sienings oor Jesus Hom tot Seun van God verhoog het. Daar is vir hom maar een verklaring: "Paulus glaubte bereits an ein solches Himmelwesen, an einen göttlichen Christus, ehe er an Jesus glaubte" (Wrede, 1907:86). Met sy bekering identifiseer Paulus Jesus met sy Christus "und übertrug nun ohne weiteres auf Jesus alle die Vorstellungen, die er van dem Himmelwesen hatte, z.B. die, dass es schon von der Welt existierte und an ihrer Erschaffung beteiligt war" (Wrede, 1907:86). Wrede voer Paulus se vermeende onbekendheid met die historiese Jesus aan as rede waarom hy Jesus as Seun van God sou aanvaar en sodoende 'n Christologie kon ontwikkel. Wrede (1907:86) is van mening dat Jesus se dissipels daarteenoor Hom te goed geken het om Hom as Skeppingsmiddelaar te aanvaar. In die lig hiervan interpreteer Wrede die Evangelies as "onmessiaans".

\subsection{Albert Schweizer en ander}

$\mathrm{Na}$ Wrede het verskeie navorsers aandag gegee aan die verhouding tussen Jesus en Paulus. Sommige was van mening dat daar veel meer punte van ooreenkoms bestaan tussen Jesus en Paulus se Christusprediking as wat Wrede wil toegee (vgl. o.a. Weiss, 1909). Hierbenewens was daar navorsers wat met die religionsgeschichtliche verklaring die insigte van Wrede verder ontwikkel het. Die verandering van Jesus tot die Christus volgens Paulus kan volgens hulle mening nie as immanente ontwikkeling verstaan word nie. Hellenisties-Oosterse agtergronde en gedagtestrome van die Nuwe-Testamentiese Umwelt word vir hierdie verandering as 
oorsaak beskou (vgl. onder andere Heitmüller, 1912:320-337; Reitzenstein, 1956 [1927]). Die besondere posisie wat Schweizer inneem, is in sy beklemtoning van die eskatologie geleë.

Schweizer beskou Paulus se "gesteigerte Zukunftserwartung" (Schweizer, 1913:188) as die groot dryfkrag agter sy teologie. Hierdie verwagting sou volgens Schweizer by Paulus tot 'n mistiek ontwikkel. Twee wêrelde word onderskei, die aardse en die boaardse. Die aardse moet deur die bo-aardse opgehef word. Dié twee wêrelde het met die opstanding van Christus inmekaar geskuif. Vir Paulus bestaan dit in die koms van die Messiaanse ryk. Deur die geloof kry die Christen deel aan hierdie ryk (Schweizer, 1913:189). In die eskatologie is die fundamentele ooreenkoms tussen Jesus en Paulus se sienings van die koninkryk geleë. Paulus sluit direk by die eskatologiese denke van Jesus aan. Die verskil is egter daarin dat Jesus die koms van die Ryk in die toekoms verwag, terwyl dit by Paulus reeds aangebreek het met die dood en opstanding van Christus. In teenstelling met Wrede handhaaf Schweizer die historiese lyn tussen Jesus en Paulus se teologie wat hy in die eskatologie begrond.

\subsection{Rudolf Bultmann}

Bultmann het in sy ondersoek na die verhouding tussen Jesus en Paulus tot die gevolgtrekking gekom dat Paulus hom vir sy teologiese, antropologiese en soteriologiese beskouings nie op die logia van Jesus beroep het nie. Enige waardering vir die persoonlikheid van Jesus ontbreek by Paulus, aangesien dit sou neerkom

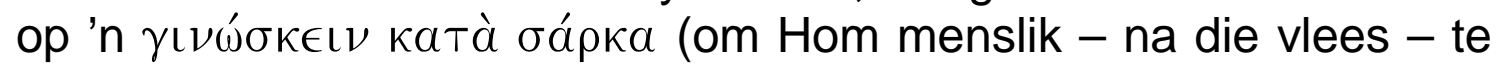

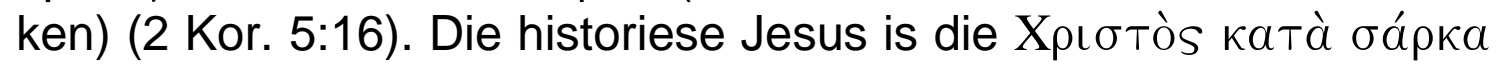
(die menslike Christus) wat verby is. "Nicht die historische Jesus, sondern Jesus Christus, der Gepredigte, is der Herr" (Bultmann, 1929a:208).

Die eschatologische und etische Verkündigung des historischen Jesus spielt bei Paulus keine Rolle ... (er) gibt aber keinen der Züge der Menschlichkeit Jesu wieder, die etwa den synoptischen Evangelien zu entnehmen wären. Das Entscheidende ist slechtin das Dass (Bultmann, 1929a:9).

Hierdie siening van Bultmann het aanleiding gegee tot die sogenaamde Dass-formulering wat 'n negatiewe oordeel oor die historiese Jesus impliseer. Met hierdie uitdrukking word bedoel dat net die feit (die Dass) van Jesus se mensheid vir die kerugma (die prediking van Paulus) van belang is. Die besonderhede van Jesus 
se aardse lewe (die Was of Wie daarvan) word nie as van deurslaggewende belang beskou nie. Paulus se Christologie word geïnterpreteer asof 'n gnostiese mite daaraan ten grondslag lê. Paulus sou dan al die verwysings na die aardse Jesus op dié mite van toepassing maak (Bultmann, 1960:224). Hierdie vermeende oordeel van die apostel oor die historiese Jesus het sedertdien by sekere groepe aksiomaties gegeld vir bepaalde rigtings wat negatief staan teenoor enige poging om agter die kerugma na die historiese Jesus te vra (Lategan, 1967:104).

\subsection{Die Joodse Jesus-en-Paulus-ondersoek}

Die belangstelling van die Joodse ondersoek in die Jesusvraag wentel rondom die ontstaansgeskiedenis van die Christendom.

Das Judentum steht hier vor seiner eigene geschichtlichen Schicksalsfrage: Wie geschah es, dass vor der jüdischen Religion sich die christliche abzweigte, und wer war der Urheber dieser schicksalschweren Entwicklung? (Lindeskog, 1938:1).

Algemene ooreenstemming volgens Joodse siening is dat as daar wel van 'n persoonlike stigter van die nuwe godsdiens sprake is, dan is dit Paulus. Jesus en Paulus word gewoonlik as twee teenpole gesien. Jesus hoort tot die Jodendom, maar Paulus nie meer nie. In talle Joodse studies kom die verskille en teenstelling tussen Jesus en Paulus se prediking telkens na vore (Buber, 1950:5; Lindeskog, 1938:582).

Paulus se erfsondeleer word as onjoods gesien, so ook sy beskouing van 'n mens se persoonlike verhouding met God en die versoening deur Jesus Christus. Die grootste beswaar is dat Paulus 'n karikatuur van die Jodendom gemaak het. Veral sy wetsopvatting sou 'n vertekening van die Tora wees. Paulus het egter nie net die Jodendom verkeerd verstaan nie: "Auch das 'Jesustum', das reine Evangelium hat er grundsätzlich verfälscht” (Lindeskog, 1938:312). Die Christendom sou eers na die dood van Jesus as sinkretistiese komplekse godsdiens ontwikkel het. "Wenn das Christentum auf einen persönlichen Stifter zurückgeht, so ist dieser Paulus und nicht Jesus von Nazareth" (Lindeskog, 1938:314). Wat die leer en lewe van Jesus betref, sou dit weinig of geen betekenis vir die teologie van Paulus gehad het.

Klausner is van mening dat Jesus ' $n$ Jood was en dat dit nooit sy bedoeling was om 'n nuwe godsdiens te stig en dit onder die heidene te propageer nie. Hy is van mening dat vanweë verskeie foute en tekortkominge van Paulus, Paulus, en nie Jesus nie, 
bewustelik daartoe oorgegaan het om 'n nuwe beweging tot stand te bring. "It is permissible to say ... that it was not Jesus who created (or more correctly, founded) Christianity, but Paul" (Klausner, 1946: 581).

\subsection{Resente navorsing}

Sedert die ontstaan van die sogenaamde "second quest" na die historiese Jesus, is die vraag oor die verhouding tussen Jesus en Paulus opnuut weer gevra (vgl. onder andere Richardson \& Hurd, 1984). Uiteraard is dit nie moontlik om 'n geheeloorsig van die navorsing in hierdie artikel te bied nie. Daar word volstaan met twee resente studies.

Wenham (1995) ondersoek die verhouding tussen Jesus en Paulus deur hooftemas uit die kanonieke Evangelies te identifiseer, naamlik die Koninkryk van God, Jesus en die samelewing, lewe in liefde, die wederkoms van die Here, en die lewe en openbare optrede van Jesus. Ook ondersoek hy die volgende vrae: Wie was Jesus? Waarom die kruisiging? Wenham gee telkens die leer volgens Jesus by elke tema weer soos dit uit die Evangelies blyk en vergelyk dit dan met die prediking van Paulus oor dieselfde temas. Op grond van hierdie vergelyking kom hy tot die gevolgtrekking dat Paulus beslis 'n volgeling van Jesus was en nie as stigter van 'n nuwe godsdiens beskou kan word nie. Paulus se gebruik van Jesus se tradisie was soepel en kreatief, maar getrou aan die gees en bedoeling van Jesus. Die hart van Paulus se teologie kan volgens Wenham (1995:410) gevind word "first (in) the Jesus whom he met on the Damascus road; second, (in) the Jesus of the Christian tradition. He of course identified the two". 'n Besondere bydrae van Wenham is sy klassifikasie van Paulus se bekendheid met die Jesus-tradisies in drie kategorieë (hoogs waarskynlik, waarskynlik en moontlik).

Hollander (2000) analiseer verwysings na Jesus in die briewe van Paulus en bring dit dan in verbinding met die samestelling van die sogenaamde Quelle (Q). Op grond van hierdie ondersoek skryf hy "From Paul's extant letters to Christian communities, we may conclude that he knew at least some things about Jesus' life on earth" (Hollander, 2000:344). Hy staan egter krities teenoor 'n benadering om parallelle te trek tussen Paulus se uitsprake wat sou ooreenstem met dié van Jesus volgens die Sinoptiese Evangelies:

These texts reflect pieces of anonymous early Christian paraenesis, which were introduced by the apostle in his letters 
to Christian communities and were ascribed to Jesus and transmitted as such elsewhere (Hollander, 2000:346).

Hy is slegs bereid om te aanvaar dat Paulus bekend was met sekere Jesus-tradisies van sy tyd. Uit Hollander se ondersoek blyk dit dat die spreuke van Jesus reeds vanaf 'n vroeë stadium oorgedra is in die geskiedenis van die vroeë Christendom soos wat dit in $Q$ sy neerslag sou vind. Wat egter belangrik is, is dat $Q$ nie 'n beskrywing van die aardse lewe van Jesus weergee soos in die vier Evangelies nie. Dit bevat omtrent net uitsprake van die historiese Jesus, maar bykans geen narratiewe stof nie (Hollander, 2000:350). Dit wil voorkom asof die eerste mondelinge en skriftelike tradisies oor die aardse Jesus meer gekonsentreer het op sy woorde as op dinge wat Hy gedoen het terwyl Hy op aarde was.

\subsection{Gevolgtrekking}

Navorsers in die Baur- en Joodse tradisies is oorwegend van mening dat daar 'n breuk tussen Jesus en Paulus bestaan. Paulus sou onder andere beïnvloed gewees het deur misteriegodsdienste en gnostiese strominge. Paulus sou idees uit hierdie strominge aan die aardse Jesus gekoppel het. Daar sou dan bloot 'n saaklike verhouding tussen Paulus se prediking en die aardse Jesus bestaan. Die ontwikkeling by Paulus weg van Jesus af word dan religionsgeschichtlich verklaar.

Tog is daar talle navorsers, waaronder Schweizer, wat eerder klem lê op die kontinuïteit tussen Jesus en Paulus. Paulus se gedagtegang sou deur die historiese Jesus bepaal wees. Meer resente navorsers toon aan dat talle tradisies oor die aardse Jesus in die tyd van Paulus bestaan het. Paulus was met ten minste 'n deel daarvan goed bekend en het daarvan gebruik gemaak in sy geskrifte.

\section{Corpus Paulinum}

Ten einde die navorsing soos hierbo bespreek te beoordeel, word verwysings na die aardse Jesus in die corpus Paulinum vervolgens ondersoek.

\subsection{Volgens menslike maatstawwe}

As vertrekpunt word die bedoeling van Paulus in 2 Korintiërs 5:16 ondersoek. Die manier waarop navorsers hierdie teks verklaar, speel 'n groot rol in hulle verstaan van die verhouding tussen Paulus en die aardse Jesus. 


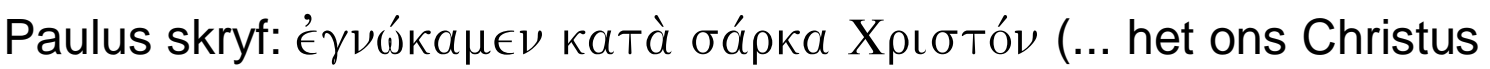
vroeër volgens menslike maatstawwe beoordeel / na die vlees geken) (2 Kor. 5:16b). Die vraag is of Paulus hier 'n uitspraak maak oor die waarde van Jesus se aardse lewe al dan nie. Menings is uiteenlopend. Weiss (1909:29) lei uit hierdie vers af dat Paulus Jesus beslis op aarde persoonlik geken het. Op grond van dieselfde gedeelte lei Reitzenstein (1956 [1927]:374) en Bousset (1970 [1921]:169) die teendeel af. Bultmann (1929b:41) is van mening dat Paulus hier bedoel dat ' $n$ mens nie die aardse Jesus as objek van geloof moet beskou nie. Bultmann verwys na Filippense 2:7 en meen Paulus verwys hier na Jesus voor sy dood en "opstanding".

Bepalend van hoe hierdie vers geïnterpreteer word, is die vraag of die bepaling "volgens menslike maatstawwe/na die vlees" (катà

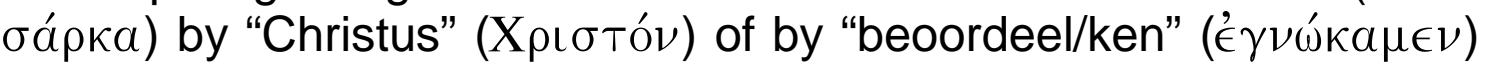
hoort (vgl. Dunn, 1998:184; Floor, 1982:25). In die eerste geval word 'n bepaalde aspek van Christus se bestaan omskryf. Dit sou impliseer dat Paulus Christus nie meer as historiese persoon, in sy liggaamlike gestalte sou ken nie. Volgens die tweede interpretasie dui dit op die manier waarop Christus geken word. Dit sou impliseer dat 'n mens Christus ken volgens die norme van die sondige natuur.

Om die volgende redes blyk dit dat die predikaat eerder met die werkwoord gelees moet word.

- Vers $16 \mathrm{~b}$ is parallel aan 16a saamgestel. By 16a ("Ons beoordeel dus van nou af niemand volgens menslike maatstawwe nie") bestaan daar nie twyfel dat die predikaat die werkwoord bepaal nie.

- Boonop word die werkwoord "beoordeel" in 16c vir 'n derde keer gebruik, en dié keer sonder predikaat - wat die aard van die "beoordeel" soos uit die vorige verse blyk, veronderstel.

- Vers 16 a en $b$ is nie net grammatikaal parallel nie, maar ook wat die bedoeling daarvan betref.

Paulus verwys blykbaar na die tyd voor sy bekering toe hy die gemeente vervolg het. "2 Cor. 5:16 refers to the turnabout in the apostle's own understanding of Christ" (Stuhlmacher, 1986:301). Morris (1990:151) verklaar dit as 'n "human life organized without reference to God and his purposes". Paulus gaan nie meer so te werk nie.

Dit is daarom duidelik dat 2 Korintiërs 5:16 nie na die aardse Jesus verwys om daardeur aan te toon dat dit nie van betekenis is vir die 
geloof nie. 'n Mens kan nie uit hierdie vers die aantyging maak dat Paulus 'n dosetistiese beskouing van Jesus gehad het nie.

\subsection{Paulus se gebruik van die name en titels}

Hahn (1969:136 e.v.) voer aan dat Jesus eers na sy kruisiging as Messias erken is. Dit blyk egter nie dat Paulus hierdie onderskeid maak nie. Uit die maniere waarop Paulus die eienaam "Jesus" met die ampsnaam "Christus", asook met die die titel "Here", "Seun van God" en "Verlosser" verbind, wil dit voorkom asof hy van die veronderstelling uitgaan dat die aardse Jesus dieselfde is as die opgestane Here.

Waar die titel Xpı бтós (Christus) in die Nuwe Testament na Jesus verwys, word dit bykans $72 \%$ van die kere deur Paulus gedoen (Morris, 1990:39). Hierdie titel word in die Nuwe Testament slegs enkele kere deur die Evangeliste gebruik om na die aardse lewe van Jesus te verwys (17 keer in Matteus, sewe keer in Markus, 12 keer in Lukas en 19 keer in Johannes). Die vroeë Christene het vroeg reeds erken dat Jesus die gesalfde van God is. Paulus formuleer hierdie erkenning dat God sy heil deur Jesus, die Christus bewerk het (Ridderbos, 1971:57). Volgens talle navorsers is dié formuleringe wat op Christus gerig is, die teologiese sentrum van Paulus se briewe (vgl. Dunn, 1998:197; Floor, 1982:69; Snyman, 1977: 230).

Paulus gebruik ook heel dikwels die menslike naam 'I $\eta \sigma o v$ s (Jesus) (214 kere) (Morris, 1990:40). Dit is opmerklik, aangesien Paulus nie 'n uitgebreide beskrywing bied van die aardse Jesus nie. Klaarblyklik wil hy deur die gebruik van die naam die werklikheid en belangrikheid van die historiese bestaan van Jesus beklemtoon. Die gebruik van hierdie menslike naam toon aan dat Paulus na ' $n$ historiese persoon verwys. Benewens die feit dat daar in die preChristelike Joodse kultus geen aanduiding is van 'n mitologiese figuur wat sou sterf en uit die dood opstaan nie, bestaan daar hoegenaamd ook nie enige verwysing na 'n mitologiese figuur met die naam Jesus nie (Foerster, 1965a:290).

Paulus kombineer dikwels die name "Jesus" en "Christus" as vaste uitdrukking (Dunn, 1998:196; Floor, 1982:58; Foerster, 1965a:289). Hy gebruik meer dikwels die volgorde "Christus Jesus" (83 kere) as "Jesus Christus" (26 keer). Wanneer hy egter die titel "Here" (кúpıos) byvoeg, keer hy meestal die volgorde om: "ons Here Jesus Christus" (54 kere) teenoor "Christus Jesus ons Here" (agt keer). Hierdie volledige titel kom 62 keer in die Pauliniese geskrifte voor, 
teenoor die skamele 19 keer in die res van die Nuwe Testament (Morris, 1990:40).

'n Besonder prominente en karakteristieke aanduiding van Jesus in die briewe van Paulus is die naam "Here" (кúpıos). Paulus gebruik die titel "Here" 275 keer, wat $38 \%$ van die totale gebruik daarvan in die Nuwe Testament verteenwoordig. Hoewel die titel "Here" ook as bloot 'n beleefde aanspreekvorm gebruik is, was dit in die Hellenistiese wêreld vir wie Paulus oorwegend geskryf het, gebruik as titel vir 'n verhewe wese en godheid (Morris, 1990:40). Vir Paulus

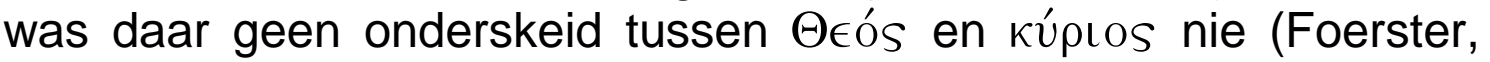
1965b:1091; Stauffer, 1965:105). Die titel kúpıos sou ook besonder betekenisvol wees vir die Joodse gemeenskap, aangesien hierdie titel gebruik is as vertaling van die Hebreeuse verbondsnaam "Jahwe" in die Septuaginta (Foerster, 1965b:1082). Paulus skryf in 1 Korintiërs 12:3:

Daarom wil ek hê dat julle moet weet dat iemand wat sê: 'Vervloek is Jesus', nie deur die Gees van God praat nie; en niemand kan sê: 'Jesus is die Here' nie, behalwe deur die Heilige Gees.

Hieruit blyk dit dat die hart van Paulus se prediking is dat Jesus die Here is (Dunn, 1998:196; Floor, 1982:52-60; Foerster, 1965b:1088).

Die kúpıos-benaming by Paulus skakel ten nouste met die benaming raîs $\theta \in o \hat{v}$ (Seun van God) (Jeremias, 1967:700). Paulus benoem Jesus vier keer as "Seun van God" en 13 keer as God "se eie Seun". Hoewel hierdie titel nie in die gewone taalgebruik altyd op 'n verhewe titel gedui het nie, was dit by Paulus, soos by die Jerusalemse kerugma, deurgaans die geval (Floor, 1982:25; Morris, 1990:41).

Paulus gebruik in enkele gevalle ook ander terme, byvoorbeeld "Verlosser" en die "laaste Adam" wat telkens op 'n verhewe titel dui (Fohrer, 1971:1015; Morris, 1990:41).

\subsection{Paulus se aanhaling van Jesus se woorde}

Hoewel Paulus in 'n beperkte mate na woorde van Jesus verwys, is dit duidelik dat hy wel met die historiese tradisies oor Jesus bekend was. Dit is so dat Paulus in sy briewe voortbou op wat reeds aan die betrokke gemeentes verkondig is (Dunn, 1998:189, 652; Floor, 1982:34), met die gevolg dat hy heelwat verwysings na die aardse Jesus sou veronderstel. Waar woorde van Jesus intrinsiek toepaslik is, gebeur dit in 'n aantal gevalle dat Paulus Jesus se woorde 
aanhaal om gesag te verleen aan sy beredenering. Die manier waarop Paulus die woorde van Jesus aanhaal, dui daarop dat hy die aardse Jesus met die opgestane Here identifiseer. Die gevolg is dat Paulus hom beroep op die gesag van Jesus as Here.

In 1 Korintiërs 7:10 verwys Paulus na 'n bevel van Jesus oor egskeiding en lui dit in met die formule "Die getroudes beveel ek nee, nie ek nie, maar die Here". Paulus beroep hom op 'n uitspraak van die aardse Jesus wat hy as die Here beskou (vgl. Dunn, 1998: 652; Floor, 1982:39; Lategan, 1967:111). Dit wil voorkom asof Paulus hier na dieselfde uitspraak van Jesus verwys as wat ook in Markus 10:11-12 et par. beskryf is. Dungan (1971:83-138) ondersoek deur middel van 'n vorm-kritiese analise die ooreenkoms tussen Paulus se aanhaling van die Here se bevel en die genoemde Sinoptiese materiaal. Uit die ondersoek blyk dit dat daar min twyfel kan bestaan dat Paulus hom op presies dieselfde tradisie beroep as wat uit die Sinoptiese Evangelies blyk. Hierdie uitspraak oor egskeiding wyk blykbaar af van die heersende standpunt van die Judaïste - daarom dat Paulus hom beroep op Jesus, wat hy as Here beskou (Barret, 1994:162). In ooreenstemming met Jesus se bedoeling volgens Markus verbied Paulus dit dat 'n geskeide vrou weer mag trou en moedig hy eerder versoening aan. As Paulus egter vanaf vers 12 die gevalle bespreek waar 'n gelowige met 'n ongelowige getroud is, is hy daarvan bewus dat hy nie oor woorde van Jesus oor die bepaalde situasie beskik nie: "Vir die ander beveel ek - ek, nie die Here nie ....".

In 1 Korintiërs 9:1 skryf die apostel: "Is ek nie 'n apostel nie? Het ek nie vir Jesus, ons Here gesien nie?" Om sy apostelskap te verdedig, beroep Paulus hom hier op die feit dat hy die Here Jesus gesien het en deur Hom uitgestuur is (Barret, 1994:201). Daarvoor verwys Paulus na 'n bepaalde historiese gebeurtenis in sy verlede. Dit is opvallend hoe Paulus telkens nadruk daarop lê dat hy sy apostelskap van die Here self ontvang het: “...'n dienaar van Christus Jesus, geroep om apostel te wees ..." (Rom. 1:1) en "Ek het dit ook nie van 'n mens ontvang of by 'n mens geleer nie. Inteendeel, Jesus Christus het dit in 'n openbaring aan my gegee" (Gal. 1:12). Soos die ander apostels sou Paulus ook getuie wees van Jesus se lewe. Uiteraard verskil die manier waarop Paulus vir Jesus gesien het van dié van die ander apostels. As getuie van die opstanding getuig Paulus ook van die lewe van Jesus voor sy opstanding.

Ook in 1 Korintiërs 9:14 beroep Paulus hom op 'n bepaling van Jesus: "So het die Here ook bepaal dat dié wat die evangelie verkondig, hulle lewensonderhoud uit die verkondiging van die 
evangelie moet ontvang". Hy verwys waarskynlik na die opdrag van Jesus wat in Matteus 10:9-10 et par. opgeteken is: "Moenie vir goud of silwer of koper in julle beursies sorg nie, en moet nie vir die pad 'n reissak aanskaf of nog 'n kledingstuk of skoene of 'n stok nie. 'n Arbeider is tog geregtig op onderhoud" (Barrett, 1994:204). Hoewel daar nie 'n woordelikse ooreenkoms bestaan nie, kom die inhoud wel saaklik ooreen (Dungan, 1971:40). Die opgestane Here is volgens Paulus die Subjek van die bepaling ("So het die Here ook bepaal ..."). Vir Paulus bestaan daar 'n kontinuïteit tussen die periode voor en na die opstanding van Jesus.

In 1 Korintiërs 11:23-25 verwys Paulus na die instelling van die Nagmaal: "Ek het van die Here ontvang wat ek ook aan julle oorgelewer het: Die Here Jesus het in die nag waarin Hy verraai is ...". Paulus stel dit duidelik dat die tradisie wat hy oordra, sy oorsprong by Jesus self gehad het. Die woorde wat Paulus gebruik, dui op tradisie in die tegniese sin van die woord - "ontvang" verwys na die Hebreeuse woord qibbel en "oorgelewer" na masar (Barrett, 1994:265). Die opgestane Here is die werklike Subjek van die oorlewering, maar Hy doen dit deur middel van menslike tussengangers. Paulus verwys na die woorde wat Jesus gebruik het en wat deur die vroeë kerk van die een na die ander oorgedra is. Hofman (1998:57) toon aan dat die tradisie wat aan Paulus oorgelewer is, sy oorsprong by die historiese Jesus gehad het en merk dan op: "niet opgeven maar getrouw doorgeven". Daarbenewens is Jesus ook die inhoud van die tradisie (Viljoen, 2002:568). Paulus beroep hom op die Here om gesag te verleen aan sy aanspraak. Hierdie aanspraak word bevestig deur die merkwaardige ooreenkoms met die Evangelies (die tradisie waarna Paulus verwys, sou sy vollediger neerslag in die Evangelies gevind het). Volgens 1 Korintiërs 11:23-25 identifiseer Paulus weereens die opgestane Here met die aardse Jesus. Jesus en die Here is vir Paulus een en dieselfde Persoon. Dit blyk ook uit die verband dat Paulus voorkennis oor die Nagmaals- en lydingsgeskiedenis by die Korintiërs veronderstel.

Volgens 2 Korintiërs 10:1 vra Paulus die gemeente "in die Naam van Christus, wat nederig en vriendelik is". Hierdie verwysing dui op die aard en gesindheid van Jesus, en dit het onder andere betrekking op Matteus 11:29: "Neem my juk op julle en leer van My, want Ek is sagmoedig en nederig van hart" en die intog van Jesus in Jerusalem op 'n donkie (Matt. 21:1-11) (Kümmel, 1975:208; Morris, 1990:302). Paulus se verwysing het ongetwyfeld betrekking op die nederigheid en sagsinnigheid van die aardse Jesus. 


\subsection{Paulus se verwysings na die aardse Jesus}

Benewens Paulus se gebruik om Jesus se woorde aan te haal of daarna te verwys, kom daar in die Pauliniese geskrifte ook verwysings na die aardse Jesus voor. Daaruit blyk dat Paulus uitgaan van die werklikheid van die aardse Persoon van Jesus. 'n Aantal voorbeelde illustreer dié punt.

In Romeine 15 vermaan Paulus die sterkes in die geloof om die swakkes in ag te neem. Hy begrond sy vermaning in die optrede van Christus:

Christus het immers ook nie aan Homself gedink nie, inteendeel. Dit was met Hom soos daar geskrywe staan: 'Die beledigings waarmee mense $U$ beledig, het op Hom afgekom' (Rom. 15:3).

Onmiskenbaar verwys Paulus hier na die somtotaal van die karakter, optrede, lyde en sterwe van die aardse Jesus (Barrett, 1991:247). Die sitaat herinner aan die dieptepunt van sy belediging - die spot van die misdadiger aan die kruis.

In 2 Korintiërs 1:5 skryf Paulus “... want net soos daar vir ons 'n oorvloed van lyding is ter wille van Christus, is daar ook vir ons 'n oorvloed van bemoediging deur Christus". Die betekenis van hierdie sinsdeel kan alleen tot sy reg kom as dit betrek word op die aardse lyding van Jesus (Lategan, 1967:140).

In 2 Korintiërs 4:10 beskryf Paulus die doodslyding wat Jesus deurgemaak het en waarin sy volgelinge hulle ook by tye bevind: "Die sterwe van Jesus dra ons altyd saam in ons liggaam ...". Die aardse Jesus is van wesenlike belang vir Paulus se prediking oor lyding. Die gelowige is ten nouste verbonde met die lyding van Jesus aan die kruis (Morris, 1990:87).

Die verwysing na Christus in 2 Korintiërs 8:9 kom in 'n paranetiese verband voor. Paulus moedig die gemeente in Korinte aan om by te dra vir die arm Christene in Judea. Dan wys hy op die oortreffende voorbeeld van Jesus Christus: "Julle ken die genade van ons Here Jesus Christus: hoewel Hy ryk was, het Hy ter wille van julle arm geword". Hierdie verwysing na sy armoede het betrekking op sy menswording en die armoede wat Hy as aardse mens gely het soos onder andere in Matteus 8:20 en Lukas 9:58 beskryf is. Gesag word aan Paulus se beroep verleen deur sy gebruik van die volle Christologiese titels vir Jesus. Die gesindheid van die aardse Jesus vorm die hart van Paulus se motivering (Martin, 1986:263). 
In Galasiërs 6:17 skryf Paulus: “... ek dra al klaar die littekens van Jesus aan my liggaam". Paulus verwys hier na die fisiese gevolge van die marteling wat hy tydens sy sendingreise deurgemaak het. Hy beskou sy liggaamlike marteling as die gevolg van sy verbondendheid met die lyding wat die aardse Jesus moes deurmaak. Paulus vereenselwig hom spesifiek met die aardse Jesus aan die kruis. "The allusion to the death of the man Jesus is probably heightened by the unusual use of Jesus' personal name, without any title (Lord or Christ)" (Dunn, 1993:237).

In Filippense 2:5-11 lees ons dat Paulus die gemeente aanmoedig om dieselfde gesindheid as Christus Jesus te openbaar. In 'n kompakte himne (2:6-11) word die heilsweg van Christus beskryf vanaf sy aanvanklike Godgelykheid tot by sy vernedering en weer tot sy uiteindelike verhoging (Floor \& Viljoen, 2002:92). In vers 7 word sy menswording beskryf ("maar Hy het Homself verneder deur die gestalte van 'n slaaf aan te neem en aan mense gelyk te word"). Die dood aan die kruis word as die dieptepunt van sy vernedering beskryf: "Hy was gehoorsaam tot die dood, ja, die dood aan die kruis" (vers 8). Daarna volg sy verhoging op grond van sy gehoorsaamheid tot die dood toe: "Daarom het God Hom ook verhef ..." (vers 9-11 e.v.). Dit is duidelik dat die aardse lewe van Jesus 'n wesenlike deel vorm van die heilsgebeure as geheel (Bockmuehl, 1997:137). Paulus maak geen skerp onderskeid tussen die verhoogde, die aardse en die pre-eksistente Christus nie. Die duidelikste bewys dat Paulus hier die werklike menswees van Jesus in gedagte het, blyk uit die feit dat die Naam op grond waarvan elke knie sal buig, Jesus is - selfs gesien vanuit die verhoging van Christus (Lategan, 1967:133).

Die gedagte van die voorsetting van Jesus se lyding en die lyding van gelowiges word duidelik in Kolossense 1:24 uitgedruk: "Ek is nou bly oor die lyding wat ek ter wille van julle moet verduur, want die vervolging van Christus het nog nie geëindig nie". Hieroor het die Here Paulus gewaarsku met sy roeping as apostel: "Ek sal vir hom wys hoeveel hy vir my Naam moet ly" (Hand. 9:16) (O'Brien, 1982:76). Die vervolging waarna Paulus verwys, dui onmiskenbaar op die lyding van die aardse Jesus.

Die gedagte van imitatio Christi kom in gedeeltes soos 1 Korintiërs 11:1; Efesiërs 5:1; 1 Tessalonisense 1:6 en 2 Tessalonisense 1:6 na vore. Paulus spoor die gelowiges aan om hom na te volg as stap in hulle navolging van Christus. Hy vermaan hulle om die voorbeeld van God se volmaaktheid na te streef. Hieruit blyk dit weereens hoe Paulus na die aardse lewe van Jesus verwys. 
Benewens bogenoemde verwysings, blyk dit uit nog talle gedeeltes dat Paulus uitgaan van die werklikheid van die historiese Jesus as grond vir sy verkondiging:

- Jesus was 'n mens (1 Kor. 15:21)

- Hy is uit 'n vrou gebore (Gal. 4:4-5)

- Hy is 'n afstammeling van Dawid (Rom. 1:3)

- Ten spyte van sy koninklike afkoms, was Hy 'n arm mens (2 Kor. 8:9)

- Hy het broers gehad (1 Kor. 9:5)

- Hy was sagmoedig en nederig (2 Kor. 10:1)

- Hy was sonder sonde (2 Kor. 5:21)

- Hy is besny en het 'n bediening onder die Jode gehad (Rom. 15:8)

- Hy het apostels gehad (Gal. 2:9)

- Sy apostels is "die twaalf" genoem (1 Kor. 15:5)

- Hy het die heilige Nagmaal ingestel (1 Kor. 11:23-25)

- Hy het voor Pilatus getuig (1 Tim. 6:13)

- Hy is deur die Jode doodgemaak (1 Tes. 2:15)

- Hy is gekruisig (Gal. 6:14)

- Hy is begrawe en het die derde dag opgestaan (1 Kor. 15:4)

\subsection{Ooreenkomste tussen Paulus en die Sinoptici oor Jesus}

Wanneer Paulus met die Sinoptici vergelyk word, bestaan daar merkwaardige ooreenkomste in hulle verwysings na die aardse Jesus. Dit blyk dat Paulus van ontwikkelende tradisies van die Urgemeinde (Hunter, 1966:77) gebruik gemaak het, wat eventueel ook hulle neerslag in die Sinoptiese Evangelies gevind het. Die verskil is egter daarin geleë dat Jesus, soos wat die Evangelies Hom beskryf, op pad is na die kruis as Viator ${ }^{3}$. Paulus daarenteen beskryf Jesus as die Here wat uit die dood uit opgestaan het en terugkyk op sy voltooide reis.

In Romeine 12:14 skryf Paulus: "Seën julle vervolgers, ja seën hulle, moet hulle nie vervloek nie". Die ooreenkoms met Jesus se woorde in die bergrede is opvallend: "Maar Ek sê vir julle: Julle moet julle vyande liefhê, en julle moet bid vir dié wat julle vervolg" (Matt. 5:44) 
(Barrett, 1991:222). Hierbenewens herinner die hele Romeine 12 (veral verse 9-12) sterk aan die bergrede.

In Romeine 14:14 skryf Paulus: "Omdat ek die Here Jesus ken, weet ek en is ek daarvan oortuig dat niks vanself onrein is nie". Paulus beroep hom op die woorde van Jesus soos in Matteus 15:11 et par. weergegee word: "Dit is nie wat by die mond ingaan wat die mond onrein maak nie. Maar wat by die mond uitkom, dit maak 'n mens onrein". Opvallend is ook Paulus se beroep op Jesus wat hy die Here noem. Uiteraard verskil Paulus se stelling hier met dié van die ortodokse Jode, met die gevolg dat hy hom op Jesus se woorde beroep (Barrett, 1991:242).

1 Korintiërs 13 kan as verdere uitbreiding van Jesus se liefdesgebod beskou word. Daar kom ook nog meer direkte toespelings op die woorde van Jesus voor. "... en al het ek al die geloof om berge te versit ..." (vers 2) kom grootliks ooreen met Matteus 17:20: "Dit verseker Ek julle: As julle maar geloof het soos 'n mosterdsaadjie, sal julle vir hierdie berg sê: 'Gaan staan daar anderkant!' en hy sal gaan ..." (Barrett, 1994:300).

\section{Kernmotiewe in Paulus se prediking oor Jesus}

'n Nadere ondersoek na kernmotiewe in Paulus se prediking oor Jesus werp verder lig op sy beskouing van die aardse Jesus.

\subsection{Jesus het die beloftes aan Israel vervul}

Paulus omskryf die betekenis van die geboorte van Jesus as die vervulling van God se beloftes aan Israel:

- Hierdie evangelie het Hy voorheen deur sy profete in die Heilige Skrif aangekondig, en dit handel oor sy Seun. As mens is Hy uit die geslag van Dawid gebore; op grond van sy opstanding uit die dood is Hy deur die Heilige Gees aangewys as die Seun van God wat met mag beklee is, Jesus Christus ons Here (Rom. 1:2-4).

- Christus het gekom om in belang van die Jode 'n dienaar te word; Hy moes vir hulle die waarheid van God bevestig deur die beloftes wat die voorvaders ontvang het, waar te maak (Rom. 15:8).

- Hy is die 'ja' van God, die 'ja' op al die beloftes van God (2 Kor. 1:20).

Paulus verwys na die Messiaanse heilsverwagting van die Jode. “... his concern (is) to insist that this gospel was not a novum or 
unexpected turn in God's purpose" (Dunn, 1998:169). Die aardse en verheerlikte Jesus word deur Paulus geïdentifiseer as dié een in wie die heil 'n werklikheid geword het (Baaij, 2003:68; Hübner, 1984:10). As sodanig bou Paulus voort op wat die apostels en die oerChristelike gemeente in Jerusalem oor Jesus as Messias verkondig het (Ridderbos, 1971:45).

Hunter (1966:80) rekonstrueer hierdie vroegste kerugma soos volg:

The prophecies are fulfilled, and the New Age has begun.

The Messiah, born of David's line, has appeared.

$\mathrm{He}$ is Jesus of Nazareth, God's Servant who

Went about doing good and healing by God's power,

Was crucified according to God's purpose,

Was raised from the dead on the third day,

Is now exalted to God's right hand,

And will come in glory for judgment.

Therefore let all repent, believe, and be baptized for the

forgiveness of sins and the gift of the Holy Spirit.

Die kontinuïteit tussen hierdie kerugma soos gerekonstrueer en dié van Paulus oor die vervulling van God se beloftes is onmiskenbaar.

\subsection{Jesus se vernedering en verhoging}

Ook wat Paulus se beskrywing van Jesus se vernedering en verhoging aangaan, is daar 'n duidelike ooreenkoms met die kerugma soos Hunter dit aanbied. In sy vernedering is Jesus ook as Seun van God beskou. Paulus gebruik hierdie hoogheidspredikaat (Seun van God) ook as hy na die aardse Jesus is sy diepste vernedering verwys. As Seun van God is Hy verneder en het Hy as Messias gely (Barrett, 1991:146; Dunn, 1993:216).

- Hy het met die sonde afgereken deur sy eie Seun in dieselfde gestalte as die sondige mens te stuur (Rom. 8:3).

- Maar toe die tyd wat God daarvoor bepaal het, aangebreek het, het Hy sy Seun gestuur. Hy is uit 'n vrou gebore en van sy geboorte af was Hy aan die wet onderworpe (Gal. 4:4).

Volgens Paulus was Jesus gedurende sy hele aardse bestaan die mensgeworde Seun van God. Jesus se lewe op aarde word nie gekontrasteer met sy bestaan as opgestane en verhoogde Here nie. Dit is onmoontlik dat Paulus 'n dosetistiese Christus in gedagte gehad het. Sy menswording en kruisiging as historiese gebeurtenisse is die manier waarop God verlossing bewerk het. 


\subsection{Jesus as objek van die geloof}

Volgens sommige navorsers het die aardse Jesus Homself nooit tot voorwerp van geloof gemaak nie, terwyl Paulus Hom die sentrale voorwerp van geloof gemaak het (vgl. Anderson, 1964:71). Die verklaring van hierdie oorgang van Jesus die Verkondiger tot Jesus die Verkondigde word as een van die grootste probleme in die Jesus-Paulus-ondersoeke beskou (Dunn, 1998:206; Lategan, 1967: 256; Wilson, 1984:12). Paulus sou verantwoordelik wees daarvoor dat die leer van Jesus omvorm is tot die leer oor Jesus (Bauer, 1973 [1864]:123; Wrede, 1907:94). Jesus was bloot die Grund, Quelle of Anhalt van die geloof, maar nooit die Gegenstand (Objek) nie (Ebeling, 1960:241). Om Jesus as die Gegenstand van die geloof te beskou, was die werk van Paulus. Die implikasie sou wees dat Jesus as voorbeeld van die regte geloofshouding van belang is, maar die beslissende heilsgebeure wat volgens Paulus in Jesus se lewe voltrek is, sou nooit ter sprake gekom het nie.

Paulus was egter nie die enigste wat Jesus as objek van die geloof beskryf nie. Ook volgens die Sinoptici het die aardse Jesus by verskeie geleenthede 'n geloofsbeslissing gevra wat sy Persoon betref:

- En gelukkig is elkeen wat nie in My begin twyfel nie (Matt. 11:6 et par.).

- Wie hom dan vir My en my woord skaam te midde van hierdie ontroue en sondige geslag, vir hom sal die Seun van die mens Hom ook skaam wanneer Hy kom saam met die engele, en beklee is met dieselfde heerlikheid as die engele (Mark. 8:38 et par.).

- Elkeen wat hom voor die mense openlik vir My uitspreek, vir hom sal Ek My ook openlik uitspreek voor my Vader wat in die hemel is. Maar hom wat My voor die mense verloën, sal Ek ook verloën voor my Vader wat in die hemel is (Matt. 10:32-33 et par.).

Hoewel sommige Nuwe-Testamentici dit betwyfel dat die Sinoptici se beskrywing oor die aardse Jesus sou verskil van wie Jesus werklik was (sien Viljoen, 2002:563-564 waar dié argumente beredeneer is), stem Paulus en die Sinoptici egter ooreen dat Jesus 'n geloofsbeslissing vereis het wat sy Persoon betref.

Ten diepste impliseer Jesus se oproepe hierbo telkens 'n geloofsbeslissing ten opsigte van sy persoon. Hierdie beslissing is wat Paulus tot uitdrukking wil bring in sy uitdrukking "geloof in Jesus Christus" (Floor, 1982:76; Snyman, 1977:233). Deur die geloof in 
Jesus kry die gelowige deel aan die heil wat God deur Hom bewerk het (Snyman, 1977:226). In teenstelling met wat Ebeling (1960:241) aanvoer, kan die fides qua (Jesus as Grund, Quelle of Anhalt) nie sonder die fides quae (Jesus as Gegenstand) bestaan nie. Ebeling se onderskeiding kan moontlik aan die eksistensieteologie toegeskryf word (Lategan, 1967:260). Die erkenning van Jesus Christus as die gekruisigde en opgestane Messias (fides quae) is tegelyk die aanvaarding van die geloof as bestaanswyse (fides qua).

Hierbenewens moet onthou word dat twee Evangelieskrywers waarskynlik by Paulus was toe hy twee van sy briewe geskryf het (Markus volgens Kol. 4:10, 14 en Lukas volgens Filem. 24) wat daarop dui dat hy ook hulle beskouing van die aardse Jesus tot sy beskikking gehad het. Stuhlmacher (1983:246) toon byvoorbeeld die waarskynlike eggo van Lukas in Romeine aan.

\section{Gevolgtrekking}

Uit die oorsig van die navorsing blyk dit dat sommige navorsers van mening is dat die besonderhede van Jesus (die wat en hoe daarvan) van geen belang vir Paulus was nie, maar bloot die dat van sy menswording. Historiese gegewens as sodanig sou vir Paulus irrelevant wees nie. Uit die eksegetiese ondersoek van hierdie artikel blyk dit egter dat hierdie onderskeid nie geregverdig is nie.

Op verskeie plekke verwys Paulus na gebeurtenisse in Jesus se aardse lewe. Hy verwys ook telkens na die gesindheid en aard van Jesus se optrede. Hy herinner gemeentes gedurig aan die voorbeeld van Jesus. Hy roep hulle op tot die navolging van Jesus en verwys dan ook na sy aardse lewe. Paulus heg teologiese betekenis aan die aardse lewe van Jesus en beroep hom telkens op woorde wat Jesus tydens sy aardse lewe uitgespreek het. Die gedeeltes wat bespreek is, handel oor Jesus se aardse lewe, lyding en opstanding en is onmiskenbaar van wesenlike belang vir Paulus se prediking.

Hoewel Paulus groot waarde aan die kruis en opstanding heg, is die besonderhede van die aardse Jesus vir hom baie belangrik en lê albei aspekte van Jesus se bestaan vir hom op 'n kontinue lyn. Vir hom word die aardse Jesus met die verhoogde Christus gekwalifiseer en insgelyk word die verhoogde Christus deur die aardse Jesus geïdentifiseer. Daarom dra die uitsprake van Jesus vir hom absolute gesag. Hy gebruik daarom ook die uitsprake van Jesus dikwels in parenetiese verband om sy eie betoog te ondersteun. 
Vanuit die situasie ná die opstanding trek Paulus verbindingslyne terug tot by die lewe van Jesus vóór sy opstanding.

Paulus se Christologie is niks anders nie as die interpretasie van Jesus se lewe en dood in die lig van die opstanding van die teenwoordige Here nie. Aangesien die aardse lewe van Jesus die voorwerp van sy interpretasie is, kan daar enersyds verklaar word waarom die aardse Jesus minder direk by Paulus ter sprake kom. Andersyds was die aardse lewe van Jesus van wesenlike belang vir Paulus se prediking.

Paulus verwys hoofsaaklik binne 'n parenetiese verband na die aardse Jesus. Hieruit blyk dit dat daar 'n direkte verband bestaan tussen die vroeë Christelike tradisie en dit wat in die Pauliniese geskrifte voorkom. Dit is sosio-histories nie korrek om Paulus se verwysings na die aardse Jesus goedskiks met die vier Evangelies te vergelyk nie. Paulus se geskrifte het op 'n vroeër stadium in die Christelike tradisie ontstaan. Wanneer Paulus met sy eietydse tradisie vergelyk word, bestaan daar 'n kongruensie. Paulus verwys dikwels na die woorde van Jesus, wat hy na alle waarskynlikheid uit die vroeë tradisie oorgeneem het - woorde wat besondere betekenis gehad het vir die vroeë Christelike gemeenskappe. Soos wat die vroeë Christelike getuienisse nie bedoel het om geskiedenis as sodanig weer te gee nie, was dit ook die geval by Paulus. Paulus wou die eerste gemeentes leer hoe om hulle Christelike geloof in die praktyk van hulle daaglikse lewe toe te pas.

Die nuwe godsdienstige beweging het kodes met voorskrifte van hulle stigter, Jesus Christus nodig gehad. Aanvanklik het hierdie kodes slegs enkele uitsprake bevat wat van toepassing was op hulle nuwe sosio-historiese omstandighede. Met verloop van tyd het hierdie kodes egter vermeerder soos wat meer en meer mondelinge tradisies oor die woorde van Jesus op skrif gestel is en by dié kodes gevoeg is. Ook verhale oor die optrede van Jesus is bygevoeg saam met ' $n$ meer gedetailleerde beskrywing van die lydingsgeskiedenis. Hierdie kodes sou uitgebrei het soos wat hierdie inligting eventueel sy neerslag gevind het in die vier Evangelies.

Dit is onmiskenbaar dat Paulus Jesus as ware historiese mens beskou het, beslis nie as 'n dosetiese Christus nie.

\section{Geraadpleegde bronne}

ANDERSON, H. 1964. Jesus and Christian origins. A commentary on modern viewpoints. New York: Oxford University Press. 
BAAIJ, P.K. 2003. Israël en de volken. Exegetische studie van Romeinen 9-11. Heerenveen: Groen.

BARRETT, C.K. 1991. Black's New Testament commentaries. The Epistle to the Romans. London: Black.

BARRETT, C.K. 1994. Black's New Testament commentaries. The First Epistle to the Corinthians. London: Black.

BAUR, F.C. 1973 [1864]. Vorlesungen über neutestamentliche Theologie. Darmstadt: Wissenschaftliche Buchgesellschaft.

BOCKMUEHL, M. 1997. Black's New Testament commentaries. The Epistle to the Philippians. London: Black.

BORNKAMM, G. 1975. Paul. London: Hodder \& Stoughton.

BOUSSET, W. 1970 [1921]. Kurios Christos. Nashville: Abingdon.

BUBER, M. 1950. Zwei Glaubensweisen. Zürich: Manesse.

BULTMANN, R. 1929a. Die Bedeutung des geschichtlichen Jesus für die Theologie des Paulus. Heidelberg: Universitätsverlag.

BULTMANN, R. 1929b. Kirche und Lehre im Neuen Testament. Zwischen den Zeiten, $7: 41$.

BULTMANN, R. 1960. Die Verhältnis der urchristlichen Christusbotschaft zum historischen Jesus. Heidelberg: Universitätsverlag.

DUNGAN, D.L. 1971. The sayings of Jesus in the churches of Paul. The use of the synoptic tradition on the regulation of the early church life. Philadelphia: Fortress.

DUNN, J.D.G. 1993. Black's New Testament commentaries. The Epistle to the Galatians. London: Black.

DUNN, J.D.G. 1998. The theology of Paul the apostle. Edinburgh: Clark.

EBELING, G. 1960. Wort und Glaube. Tübingen: Mohr.

FLOOR, L. 1982. Perspektiewe op die prediking van Paulus. Pretoria: NG Kerkboekhandel.

FLOOR, L. \& VILJOEN, F.P. 2002. Die Christus-himne in Filippense: soteriologies of eties? In die Skriflig, 36(1):91-104.

FOERSTER, W. 1965a.' Inoous. (In Kittel, G. \& Friedrich, G., eds. Theological Dictionary of the New Testament. Vol. 3. Michigan: Eerdmans. p. 284293.)

FOERSTER, W. 1965b. kúpıos. (In Kittel, G. \& Friedrich, G., eds. Theological Dictionary of the New Testament. Vol. 3. Michigan: Eerdmans. p. 10811098.)

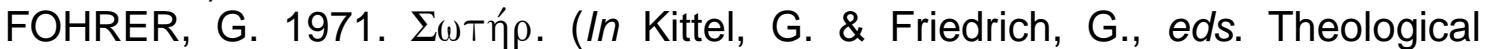
Dictionary of the New Testament. Vol. 7. Michigan: Eerdmans. p. 10131023.)

HAHN, F. 1969. The titles of Jesus in Christology. London: Lutterworth.

HEITMÜLLER, W. 1912. Zum Problem Paulus und Jesus. Zeitschrift für die neutestamentliche Wissenschaft und die Kunde der älteren Kirche, 13:320-337.

HOFMAN, T.M. 1998. Doorgeven of opgeven? Apeldoorn: Theologische Universiteit. (Apeldoornse Studies no. 38.)

HOLLANDER, H.W. 2000. The words of Jesus: form oral traditions to written record in Paul and Q. Novum Testamentum, 42(4):340-357.

HOLZMANN, H.J. 1897. Lehrbuch der neutestamentlichen Theologie II. Freiburg-Leipzig: Mohr.

HÜBNER, H. 1984. Gottes Ich und Israel. Zum Schriftgebrauch des Paulus in Römer 9-11. Göttingen: Vandenhoeck. 
HUNTER, A.M. 1966. The Gospel according to St. Paul. London: SCM.

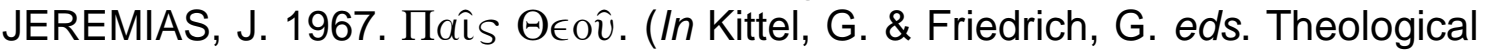
Dictionary of the New Testament. Vol. 5. Michigan: Eerdmans. p. 677717.)

KÜMMEL, W.G. 1958. Das Neue Testament. Geschichte der Erforschung seiner Probleme. Freiburg/München: Karl Alber.

KÜMMEL, W.G. 1975. Introduction to the New Testament. Nashville: Abingdon.

KLAUSNER, J. 1946. From Jesus to Paul. London: Allen \& Unwin.

LATEGAN, B.C. 1967. Die aardse Jesus in die prediking van Paulus volgens sy briewe. Rotterdam: Bronder-offset.

LINDESKOG, G. 1938. Die Jesusfrage im neuzeitlichen Judentum. Ein Beitrag zur Geschichte der Leben-Jesu-Forschung. Uppsala: Lindequistska Bokhandeln.

MARTIN, R.P. 1986. Word Biblical commentary. Volume 40. 2 Corinthians. Waco: Word Books.

MORRIS, L. 1990. New Testament Theology. Grand Rapids, Michigan: Zondervan.

O'BRIEN, P.T. 1982. Word Biblical commentary. Volume 44. Colossians, Philemon. Waco: Word Books.

REITZENSTEIN, R. 1956 [1927]. Die hellenistischen Mysterienreligionen nach ihren Grundgedanken und Wirkungen. Leipzig-Berlin: Teubner.

RICHARDSON, P. \& HURD, J.C., eds. 1984. From Jesus to Paul. Studies in honour of Francis Wright Beare. Waterloo: Wilfred Laurier University Press.

RIDDERBOS, H. 1971. Paulus. Ontwerp van zijn theologie. Kok: Kampen.

SCHMITHALS, W. 1962. Paulus und der historische Jesus. Zeitschrift für neutestamentliche Wissenschaft und die Kunde der älteren Kirche, 53:145-160.

SCHWEIZER, A. 1911. Die Geschichte der paulinischen Forschung von der Reformation bis auf die Gegenwart. Tübingen: Mohr.

SCHWEIZER, A. 1913. Geschichte der Leben-Jesu-Forschung. Tübingen: Mohr.

SNYMAN, W.J. 1977. Nuwe en ou dinge "uit die skat van die koninkryk". Potchefstroom: Pro Rege.

STAUFFER, E. 1965. E€ós. (In Kittel, G. \& Friedrich, G., eds. Theological Dictionary of the New Testament. Vol. 3. Michigan: Eerdmans. p. 94-121.)

STUHLMACHER, P. 1983. Jesustradition im Römerbrief. Theologische Beiträge, 14:240-250.

STUHLMACHER, P. 1986. Reconciliation, law and righteousness: Essays in Biblical theology. Philadelphia: Fortress.

VAN AARDE, A.G. 2001. Fatherless in Galilee: Jesus as child of God. Harrisburg, PA: Trinity Press International.

VAN AARDE, A.G. 2002. Die "evangelie" van Paulus. Verbum et Ecclesia, 23(2):516-532.

VILJOEN, F.P. 2002. Jesus sonder Christus of Christus sonder Jesus? In die Skriflig, 36(4):555-572.

WEISS, J. 1909. Paulus und Jesus. Berlin: Reuther \& Reichard.

WENHAM, D. 1995. Paul: Follower of Jesus or founder of Christianity? Grand Rapids: Eerdmans. 
WILSON, S.G. 1984. From Jesus to Paul: The contours and consequences of a debate. (In Richardson, P. \& Hurd, J.C., eds. From Jesus to Paul. Studies in honour of Francis Wright Beare. Waterloo: Wilfred Laurier University Press. p. 1-21.)

WREDE, W. 1907. Paulus. Tübingen: Möhr.

\section{Kernbegrippe:}

historiese Jesus-navorsing

Jesus as mens: Paulus se beskouing van

Key concepts:

historical Jesus research

Jesus as man: Paul's views on 
